Another group of anomalies in the Kap Simpson complex was investigated and proved to be caused by a dark acid lava with slightly increased radioactivity.

Both intrusive complexes are rich in sulphides and pneumatolytic to hydrothermal activity has created spectacularly coloured zones of alteration. None of these zones showed increased radioactivity.

\title{
References
}

Nielsen, B. L. \& Larsen, H. C. 1974: Airborne geophysical survey in central East Greenland. Rapp. Grønlands geol. Unders. 65, 73-76.

Nielsen, B. L. \& Steenfelt, A. 1975: Prospecting for uranium in central East Greenland. Rapp. Grønlands geol. Unders. 75, 107-110.

Steenfelt, A. 1976: Uranium exploration in northern East Greenland. Rapp. Grønlands geol. Unders. 80, 110-112.

\section{Structural and metamorphic studies in the East Greenland Caledonides between $72^{\circ}$ and $74^{\circ} \mathrm{N}$}

\section{Tage Thyrsted}

In 1975 and 1976 investigations were carried out in the East Greenland Caledonides in the region between $72^{\circ}$ and $74^{\circ} \mathrm{N}$ with special reference to basement-cover relationships and regional metamorphic studies and backed up by isotopic studies (Friderichsen \& Higgins, 1976; Higgins et al., 1977).

In 1977 the work comprised mainly metamorphic investigations. Short descriptions of the localities visited are given below.

\section{Southern Louise Boyd Land}

A section was studied in an arid sandy valley ('Desert Valley', fig. 32) closely comparable to the Knækdal section to the south visited in 1976 (Higgins et al., 1977, p. 112). In the western two thirds of the valley the late Precambrian sediments of the Petermann Series are exposed, comprising from top to bottom the Summit 'series', the Layered 'series', the Phyllite 'series', and the Mystery Quartzite 'series'. The last-named is more completely represented in southern Louise Boyd Land than in Knækdal, attaining an estimated thickness of $3500 \mathrm{~m}$ (tectonic thickening cannot be excluded).

Underlying the Petermann Series a sequence of metasediments consists of about $700 \mathrm{~m}$ of rusty mica schist with numerous sheets of two-mica granite, and underlain by an almost $2 \mathrm{~km}$ thick unit of semipelitic to quartzitic schists. The boundary with the overlying series seems to be concordant. 


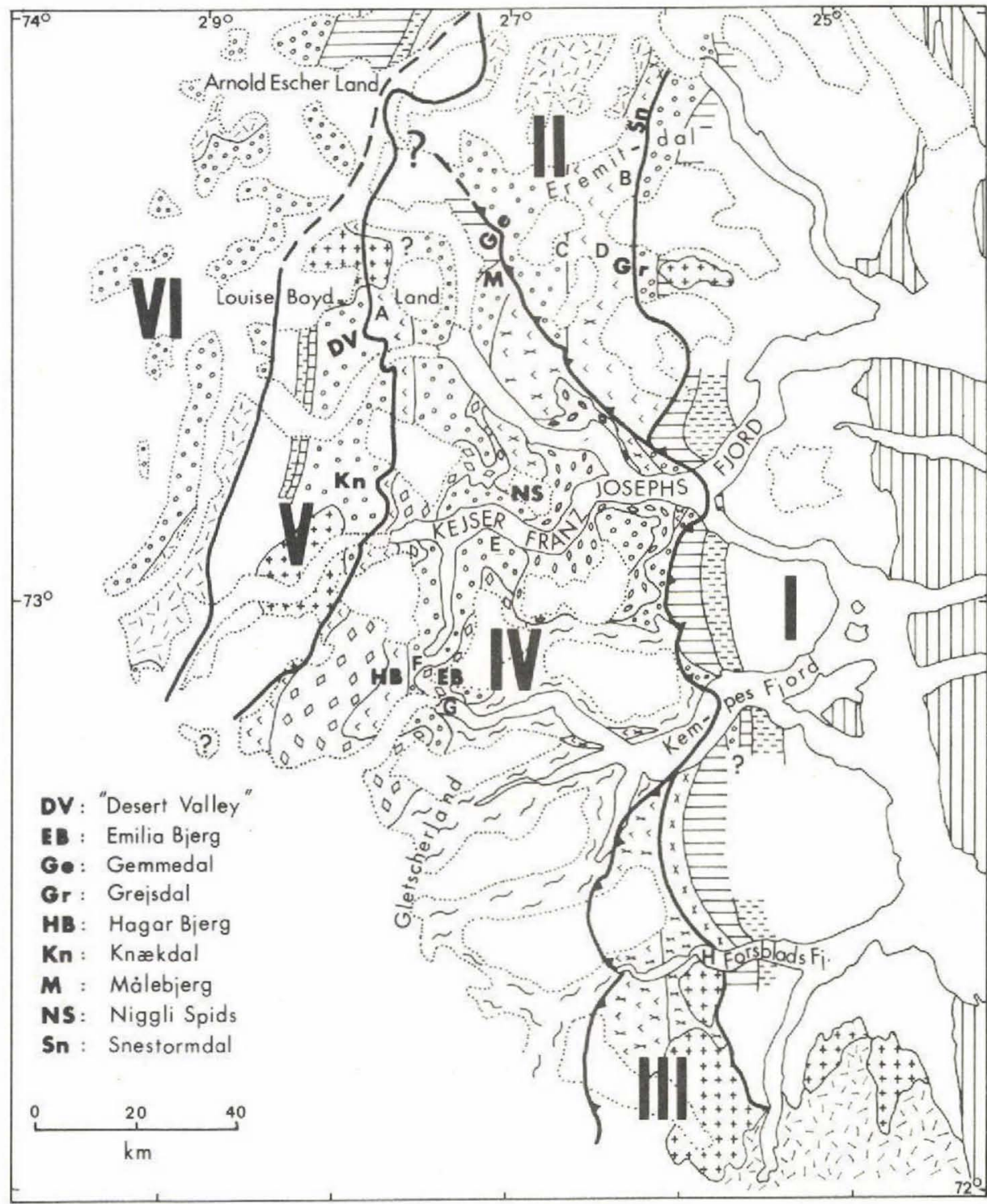

Gletscherland Complex

$\diamond \otimes$ Hagar Sheet

\%: Niggli Spids Dome

[1) Uncifferentiated gneisses
Sedimentary rocks and schists of any arigin.

Metamorphic symbols superimposed

$\left[\begin{array}{l}+++ \\ +++\end{array}\right.$ Late orogenic granites Post-Caledonian rocks
METAMORPHIC SYMBOLS

\begin{tabular}{|c|c|}
\hline$\because=$ & Chlorite \\
\hline & Biotite \\
\hline$\because$ & Garnet \\
\hline$x^{x} x^{x}$ & Staurolite \\
\hline$c_{3}<$ & Kyanite \\
\hline$=-$ & Sillimanite \\
\hline
\end{tabular}

Fig. 32. Geological sketch map of northern East Greenland between $72^{\circ}$ and $74^{\circ} \mathrm{N}$, showing the proposed regional metamorphic zones. Letters $\mathrm{A}-\mathrm{H}$ indicate the locations of the whole-rock specimens collected in 1977. 
The easternmost $1.5 \mathrm{~km}$ of the valley is made up of light-coloured, garnetiferous augen gneiss in which the augen reach up to $5 \mathrm{~cm}$ across. The boundary with the overlying schist sequence appears generally concordant; locally a slight discordance may be seen, although close to the boundary the foliation is rotated into parallelism with the contact.

The rock units in southern Louise Boyd Land are strongly folded. To the west in the Petermann Series the bedding is folded into macroscopic folds with axes plunging shallowly to the south or south-south-east, parallel to the mineral lineation in the rocks. In the Mystery Quartzite 'series' a major recumbent fold was observed, comparable in style to the Mysteriesøer overfold noted by Odell (1939) in Knækdal. In the eastern part of the valley the linear features (lineations and fold axes) generally plunge shallowly towards the north-west.

The metamorphic grade increases progressively from west to east, beginning with low-grade chlorite-muscovite slates, with successively biotite and garnet appearing, the latter in the upper part of the Phyllite 'series'.

\section{Eremitdal and Grejsdal (Andrée Land)}

These valleys are situated at the eastern contact of the so-called central metamorphic complex with the late Precambrian Eleonore Bay Group. Eremitdal lies about $20 \mathrm{~km}$ north of Grejsdal but the sections exposed in them are fairly similar.

To the east in both valleys the Eleonore Bay Group is represented by the Quartzite 'series' and the Upper Argillaceous - Arenaceous 'series'. At least two fold phases can be recognised. The fold axes trend $\mathrm{N}-\mathrm{S}$ and are locally coaxial with a mineral lineation. Elsewhere, however, the lineation has an E-W trend. Metamorphism increases from east to west with garnet as the highest grade mineral.

Below the Eleonore Bay Group a schist sequence of mainly semipelitic to quartzitic composition is found (the 'Grejsdal schists'). The contact between the two successions is apparently concordant. Zones of brecciation and minor mylonite zones are characteristic of the contact area but the regional importance of these zones is not known. There is, however, an abrupt and consistent change in the orientation of the linear features from a generally $\mathrm{N}-\mathrm{S}$ direction in the Eleonore Bay Group to a NW-SE trend in the underlying 'Grejsdal schists'. At the same time there is a change in fold style from the open to tight, generally upright folds characteristic of the Eleonore Bay Group to tight, inclined or recumbent folds in the schists. Sheets of mainly foliated, garnet-bearing two-mica granites are numerous in the schist sequence and commonly are also involved in the folding.

Apart from augen gneisses found at the north-west corner of the Eremitdal-Snestormdal junction (fig. 32) no gneiss and amphibolite complexes of 'basement' character were encountered in the two valleys.

\section{Gemmedal-Målebjerg (Andrée Land)}

Gemmedal is the western extension of Eremitdal and the rocks found in upper Gemmedal are considered to belong to the 'Grejsdal schists'. In upper Gemmedal the sequence is represented by grey garnet-mica schists, underlain by, and in its lower part interlayered with, a light grey, garnet-bearing siliceous schist or gneiss. 
The 'Grejsdal schists' in middle Gemmedal are thrust over an approximately $900 \mathrm{~m}$ thick metasedimentary sequence found in lower Gemmedal and at Målebjerg. The lowest unit of this metasedimentary sequence (the 'Gemmedal sequence') consists of about $100 \mathrm{~m}$ of very pure, white quartzite, overlain by a $350 \mathrm{~m}$ thick marble-calcareous schist unit; the lower 120 $\mathrm{m}$ of the latter consists almost exclusively of medium grey, weakly folded calcareous schists, while in the upper part interlayering of conspicuous light-yellow marble also occurs. The 'Gemmedal sequence' is terminated by a $450 \mathrm{~m}$ thick, well-layered unit of alternating quartzitic and pelitic schists.

Beneath the 'Gemmedal sequence' at Målebjerg a greenish-grey rock unit occurs, varying in appearance from a phyllitic schist to an augen-textured gneiss. Local veining with quartz/feldspar material gives the rock a migmatitic appearance. This rock unit corresponds to the 'Sericite-chlorite schist to augen gneiss' of Haller (1971, p. 86) which was included by Haller in his Målebjerg Series. However, the new studies reveal strong indications for an angular unconformity between the units, and the schist-gneiss rock unit is considered to belong to a distinct lower sequence.

In the Gemmedal-Målebjerg region there are thus three rock sequences separated by two discordances. The contact between the 'Grejsdal schists' and the 'Gemmedal sequence' is a thrust zone, and part of a major thrust system transecting the whole region (fig. 32). In the Gemmedal-Målebjerg area the foliation in the 'Grejsdal schists' is rotated parallel to the thrust zone. Furthermore, there is a metamorphic jump across the thrust from the higher grade, overlying 'Grejsdal schists' to the lower grade, underlying 'Gemmedal sequence'. Yet a retrogression has occurred in the 'Grejsdal schists' with complete chloritisation of the garnets close to the thrust zone.

\section{Regional metamorphic zones}

To describe the regional metamorphic zones it is convenient to divide the region investigated into six sub-areas (fig. 32).

Area $I$ comprises the late Precambrian Lower and Upper Eleonore Bay Group, the Eocambrian Tillite Group, and Cambro-Ordovician sediments. Deformation of the rocks and the metamorphism seen mainly in the Eleonore Bay Group are of Caledonian age.

There is an increase in metamorphism from east to west. To the east the rocks are unmetamorphosed, while going westwards the chlorite, biotite, garnet, and in the south the staurolite isograds, are successively crossed.

In the south at Kempes Fjord an isolated garnet zone was detected within the biotite zone, and in both Kempes Fjord and Forsblads Fjord the staurolite zone seems to replace the biotite zone directly without any intermediate garnet zone. To the north garnet is the highest grade mineral.

Area II is mainly made up of the 'Grejsdal schists', with 'basement-like' augen gneisses in the north. The boundary with area $I$ is apparently transitional. The age of the schists is not known, but collections have been made for whole-rock isotopic studies (localities B-D, fig. 32).

To the east in this area there is a $15 \mathrm{~km}$ wide zone bearing kyanite, in the north close to the boundary with area I occurring together with staurolite, and in the middle of the zone with sillimanite. The western part of the area is mainly of garnet grade. 
Area III mainly consists of high-grade, migmatite schists and migmatitic granites. Its boundary with area $I$ is apparently transitional and is even of uncertain location. A whole rock 'errorchron' from the head of Forsblads Fjord has given an age of $1270 \pm 100$ m.y. (Rex et al., 1977). Further collections for whole rock analysis were made in the middle part of the fjord (locality $\mathrm{H}$, fig. 32 ).

In this area sillimanite occurs throughout. To the east a zone occurs in which garnet and sillimanite are the highest metamorphic minerals, while in the western part of the area kyanite also occurs.

Area IV is built up of three crystalline complexes (the Gletscherland migmatite complex, the Hagar migmatite sheet and the Niggli Spids migmatite dome), which are separated by and partly infolded with a supracrustal schist sequence. The widespread occurrences of marbles and calcareous schists in this sequence suggest that the schists all belong to the same unit, corresponding to the 'Gemmedal sequence' although thicknesses vary. The boundary with areas I, II, and III is a thrust zone.

The Gletscherland migmatite complex has given ages of $2500 \mathrm{~m} . \mathrm{y}$., $1870 \pm 36 \mathrm{~m} . \mathrm{y}$. , and $1740 \pm 13$ m.y. (Rex et al., 1976, 1977), and similar ages (unpublished) have been obtained from parts of the Hagar migmatite sheet (A. R. Gledhill, personal communication). Further collections for isotopic work were made from three localities (E-G).

The metamorphic pattern is complex. In general high-grade zones occur along the margins of the area. In the east sillimanite and kyanite co-exist everywhere, while in the west kyanite alone represents the highest grade mineral. In a central part a garnet zone is found, but high An-content in plagioclase indicates that amphibolite facies conditions were also reached here.

Area $V$ comprises the Petermann Series, which is correlated with the Eleonore Bay Group of area I; their deformation and metamorphism are of Caledonian age.

Metamorphic grade increases from west to east, from unmetamorphosed rocks, through chlorite, biotite and garnet zones. The broad garnet zone $(10-15 \mathrm{~km})$ is characteristic. One occurrence of kyanite has been noted in northern Louise Boyd Land.

Area $V I$ is a remote region of mainly nunataks known only from reconnaissance trips. The boundary with area $\mathrm{V}$ is a fault. The rocks comprise various gneisses and quartzitic schists, the former comparable with the crystalline complexes of area IV, while the schists may be correlated with either the Eleonore Bay Group or with the older schist sequences. In Arnold Escher Land low-grade sediments and volcanics of uncertain age occur.

From investigation of the few specimens from the nunatak region the schists seem to be metamorphosed to garnet grade. In Arnold Escher Land a chlorite, biotite, and garnet zone can be observed, but the metamorphic increase is in the reverse direction to that known in area $\mathrm{V}$.

\section{Acknowledgement}

The metamorphic investigations have been carried out with the support of the Danish Natural Science Research Council (SNF), which is gratefully acknowledged. 


\section{References}

Friderichsen, J. D. \& Higgins, A. K. 1976: Reconnaissance work in the crystalline complexes of northern East Greenland between $72^{\circ}$ and $74^{\circ} \mathrm{N}$. Rapp. Gronlands geol. Unders. 80, 98-102.

Haller, J. 1971: Geology of the East Greenland Caledonides, 413 pp. New York: Interscience Publishers.

Higgins, A. K., Friderichsen, J. D. \& Thyrsted, T. 1977: Basement-cover relationships and metamorphic studies in the East Greenland Caledonides $\left(72^{\circ}-74^{\circ} \mathrm{N}\right)$. Rapp. Grønlands geol. Unders 85 , 109-114.

Odell, N. E. 1939: The structure of the Kejser Franz Josephs Fjord Region, North-East Greenland. Meddr Grønland 119,6, 53 pp.

Rex, D. C., Gledhill, A. R. \& Higgins, A. K. 1976: Progress report on geochronological investigations in the crystalline complexes of the East Greenland Caledonian fold belt between $72^{\circ}$ and $74^{\circ}$ N. Rapp. Grønlands geol Unders. 80, 127-133.

Rex, D. C., Gledhill, A. R. \& Higgins, A. K. 1977: Precambrian Rb-Sr isochron ages from the crystalline complexes of inner Forsblads Fjord, East Greenland fold belt. Rapp. Grønlands geol. Unders. 85, $122-126$.

Geologisch en Mineralogisch Instituut, Rijksuniversiteit,

Garenmarkt $1 \mathrm{~b}$,

Leiden,

The Netherlands.

\section{The Jurassic of Milne Land, central East Greenland}

\section{T. Birkelund, J. H. Callomon and F. T. Fürsich}

In 1977 field work on the Jurassic of Milne Land (fig. 33) by the authors and C. Heinberg, S. Piasecki and $\mathbf{L}$. Stemmerik was mainly concerned with detailed recording of sections, biostratigraphical and palaeoecological investigations.

\section{Stratigraphy}

On the basis of the new detailed work combined with work carried out by J. H. Callomon in 1957-1958 as part of Lauge Koch's expeditions, formal lithological units can now be established for the Jurassic deposits of Milne Land (fig. 34). Since these units will be named and described in detail elsewhere this account is only a brief summary. Established lithological units have been retained where possible, although some have had their boundaries revised.

In what follows, formations and members are described in ascending order. Further 